\title{
Global emission hotspots of coal power generation
}

\section{Journal Article}

Author(s):

Oberschelp, Christopher (1); Pfister, Stephan (1); Raptis, Catherine (i); Hellweg, Stefanie (i)

Publication date:

2019-02

Permanent link:

https://doi.org/10.3929/ethz-b-000324460

Rights / license:

In Copyright - Non-Commercial Use Permitted

Originally published in:

Nature Sustainability 2, https://doi.org/10.1038/s41893-019-0221-6 


\title{
Global emission hotspots of coal power generation
}

\author{
C. Oberschelp ${ }^{a}$, S. Pfister ${ }^{a}$, C. E. Raptis ${ }^{\text {a }}$, and S. Hellweg ${ }^{a}$ \\ ${ }^{a}$ ETH Zürich, Institute of Environmental Engineering, John-von-Neumann-Weg 9, CH-8093 Zurich, Switzerland
}

This document represents the final draft ('post-print') of a manuscript that was submitted to Nature Sustainability on 28 December 2018. The paper has been published on 11 March 2019 at https://doi.org/10. 1038/s41893-019-0221-6. For direct access to the publisher version without Nature Sustainability subscription, please go to https://rdcu. be/bmcVk. The full result dataset is available from https://doi.org/10. 17632/dm3rjb9ymc.1.

Coal power generation is a primary cause of greenhouse gas (GHG) and toxic airborne emissions globally. We present a uniquely comprehensive inventory of $\mathrm{CO}_{2}$, methane, particulate matter, sulfur dioxide, nitrogen oxides, and mercury emissions for 7861 coal generating units including their supply chains.

Total GHG and toxic substance emissions are largest from China, US, India, Germany and Russia (together $>64 \%$ per pollutant). Overall supply chain contributions are below $19 \%$, but exceed $75 \%$ for individual units and pollutants. Methane emissions from underground coal mining offset Chinese coal power plant efficiency advantages in comparison to India. Health impacts, as quantified by regionalized life cycle assessment, are highest in India and parts of eastern and south-eastern Europe due to lack of modern flue gas treatment, and in China due to widespread coal power generation. Deployment of state-of-the-art flue gas treatment, driven by local emission limits, can mitigate health impacts in India and parts of Europe while it is already largely used in China and the US. Phase-out of the $10 \%$ most polluting coal power plants (by capacity) would reduce coal power GHG emissions by $16 \%$ or human health impacts by $64 \%$, respectively.

A mbient air pollution is the primary environmental threat to human health globally (1). Combustion of fossil fuels, including coal, is the main anthropogenic contributor $(2,3)$. Coal combustion releases $\mathrm{CO}_{2}$ as well as fine particulate matter $\left(\mathrm{PM}_{2.5}\right)$ and its gaseous precursors sulfur dioxide $\left(\mathrm{SO}_{2}\right)$ and nitrogen oxides $\left(\mathrm{NO}_{\mathrm{x}}\right)$ into the air. $\mathrm{CO}_{2}$ drives climate change, while $\mathrm{PM}_{2.5}$ can enter human lungs and cause ischemic heart disease and stroke, chronic obstructive pulmonary disease, lung cancer among adults and acute lower respiratory tract infections among children. Additionally, airborne $\mathrm{SO}_{2}$ from fuel sulfur can cause acid rain (2). $\mathrm{NO}_{\mathrm{x}}$ emissions are toxic and contribute to global warming and terrestrial acidification. Finally, mercury, with its high toxicity, long-term persistency and potential to affect children's brain development, is released to air by coal combustion (4). Once deposited, it may build up in the aquatic food chain and be ingested by humans. Reducing impacts from these emissions is a global priority, but further industrialization, especially in China and India, poses the risk of aggravating the situation instead.

During the transition to renewable, more sustainable alternatives, coal combustion techniques need to improve by targeting the causes of pollution impacts. Existing studies $(5-11)$ however, are unable to identify the most effective mitigation options on plant-level due to lack of spatial resolution, supply chain coverage and regionalized quantification of health impacts (discussed in detail in the supplementary information
(SI)). Thus, there is a clear need for a global model that combines technological standards and supply-chain characteristics of each power plant and allows for the derivation of reliable decision support for the mitigation of human and environmental exposure. To tackle this issue, the present work provides the most detailed global picture of site-specific airborne coal power plant emissions, including mining, coal preparation, trade and transport, mechanistic power plant modeling and flue gas treatment. Emissions are quantified for $\mathrm{CO}_{2}, \mathrm{CH}_{4}$, $\mathrm{PM}_{2.5}, \mathrm{PM}_{10-2.5}, \mathrm{PM}_{>10}, \mathrm{SO}_{2}, \mathrm{NO}_{\mathrm{x}}$, and three species of mercury $\left(\mathrm{Hg}^{0}, \mathrm{Hg}^{2+}\right.$, and $\left.\mathrm{Hg}_{p}\right)$, which have been identified as key pollutants $(7,9)$. Health and climate change impacts are quantified, technical abatement potential is analyzed in an unprecedented level of detail, and key policy implications are provided.

Global coal supply and emissions. Emissions from coal power plants depend on coal qualities and combustion mechanics. We therefore first connect the coal quality (broken into four ranks) associated with individual coal mines to power plants using a transport model. This model uses plant-specific coal origin data where possible, and otherwise uses coal that minimizes transport costs with respect to national and province-level coal trade data. The coal ranks are comprised of anthracite, bituminous coal, subbituminous coal, and lignite (in order of decreasing calorific value). Global patterns of coal transport from mines to power plants for the year 2012 are presented in figure 1.

The main coal mining regions are located in China and the US. However, Indonesia, Australia, Russia, South Africa, and Colombia also produce large amounts of coal. Mining activities contribute significantly to total greenhouse gas (GHG) emissions (quantified with GWP100 (12), 5\%) and $\mathrm{NO}_{\mathbf{x}}(9 \%)$ emissions of coal power generation (details in the SI). Methane emissions from underground coal mining harm the climate and represent the waste of a resource that could be used for energy supply (13). For countries without proper mine management, these emissions can account for up to $13 \%$ of their total GHG emissions along the coal power value chain (figure $2 \mathrm{~b}$ ). $\mathrm{NO}_{\mathrm{x}}$ emissions are caused mostly from the operation of mining equipment and blasting (14) and are in a few extreme cases responsible for up to $68 \%$ of total $\mathrm{NO}_{\mathrm{x}}$ emissions from coal power generation. Additional emissions are caused by uncontrolled coal fires but reliable data on these is not available (15) and hence, is not included. Coal washing is practiced in major coal-producing countries like China, Australia, and the US, and for bituminous export coal around the world. This improves coal quality by increasing the calorific value per weight and decreasing impurities like ash, sulfur and mercury content but increases water-borne emissions. Effects of coal washing on power plant emissions are calculated per country, coal rank and destination.

Coal transport is largely due to the international trade of bituminous coal, which is favored due to its low ash content and high calorific value. In contrast, lignite is of low quality and is therefore hardly traded internationally. Global coal 


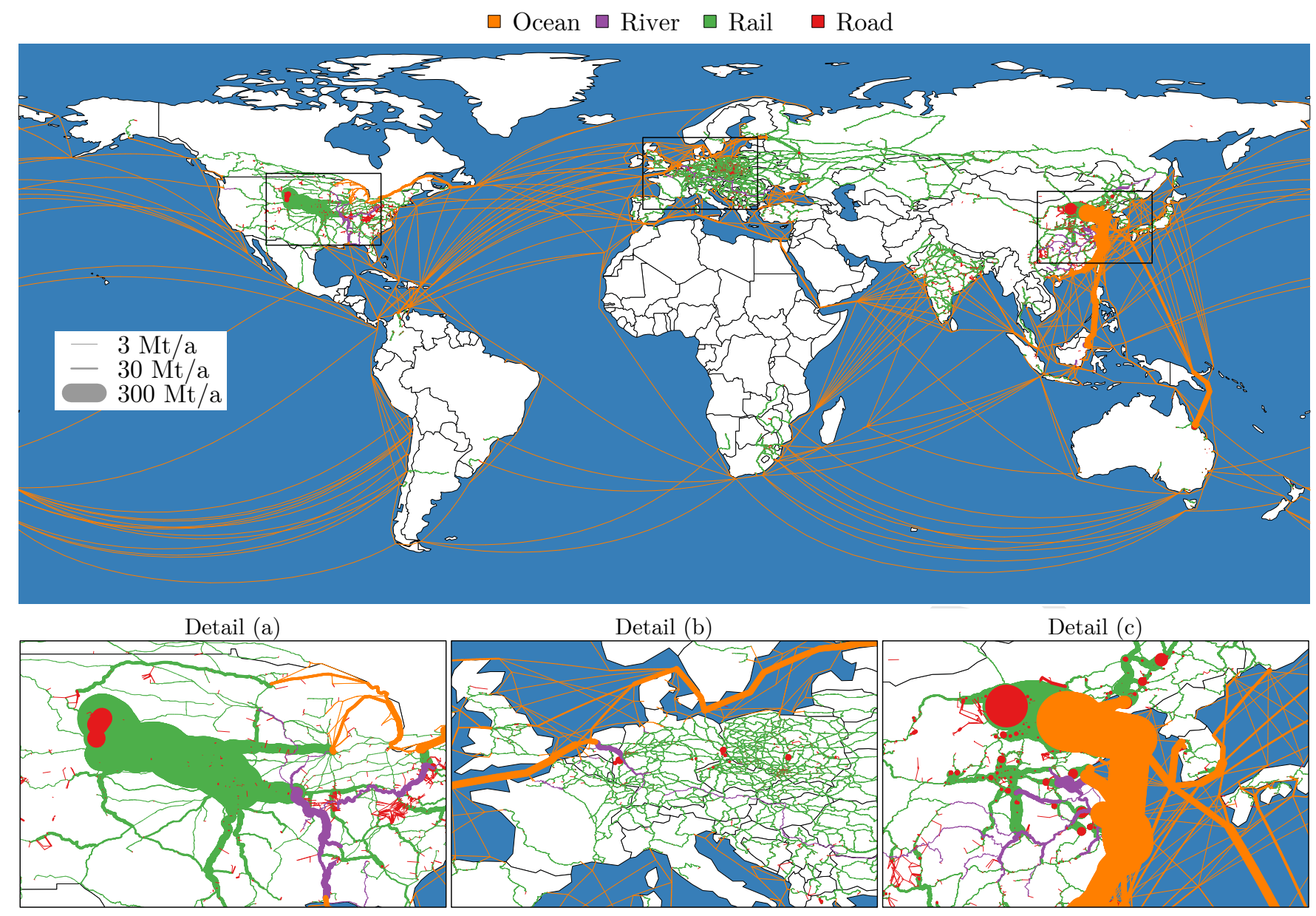

Fig. 1. Globally modeled coal transport amounts from mines to power plants for four transport modes in 2012. Line width is proportional to transported mass. Details show parts of North America (a), Europe (b) and Asia (c) magnified by a factor of 3.7.

transport equals 5800 bn tkm which amounts to $19 \%$ of the global sea and ground transport in 2012 (16). About $66 \%$ is transported via ocean ships, $30 \%$ via train and the rest is transported via truck or barge. Ocean transport is largely driven by the Chinese coal import over long distances from Australia, Indonesia, South Africa and North America (figure 1, detail (c)). Other main coal ocean transport is from Colombia and Russia to Central Europe (figure 1, detail (b)), as well as from Australia, Indonesia and South Africa to Europe, Japan and India.

As China is the largest consumer of coal globally (39 wt.- $\%$ ), much of the transport happens inside China itself with $80 \%$ by train, $13 \%$ by barge, and $7 \%$ by truck. Chinese coal transport generally involves northern coal mines shipping southward or central and southern mines shipping eastward. The US is second-largest consumer globally (19wt.-\%). The main regions of resulting US rail transport are located in the center of the US and close to the Appalachians (17). The distribution of $232 \mathrm{Mt}$ of subbituminous coal from Wyoming eastwards is responsible for the main coal train transport by tkm globally in 2012 (figure 1, detail (a)).

Transport emissions are mostly from long-distance transport via ocean-going ships and medium-distance transport via train. The ships mostly add to the total emissions of $\mathrm{SO}_{2}$,
$\mathrm{NO}_{\mathrm{x}}$ and $\mathrm{PM}_{2.5}$ via their combustion of fuel oils for propulsion. These emissions may not be critical in remote areas, but they can have substantial health and ecological impacts close to the shore. Ocean transport emissions are particularly high along the Chinese coast. On average, ocean transport accounts for $1.7 \%$ of $\mathrm{SO}_{2}$ and $\mathrm{PM}_{2.5}$ emissions, and for $4.2 \%$ of $\mathrm{NO}_{x}$ emissions (figure 2c-e). These emissions could be reduced by the use of higher quality ship fuel. Fuel combustion is also the main cause for high $\mathrm{NO}_{\mathrm{x}}$ and $\mathrm{PM}_{2.5}$ emissions from rail transport (18) that contribute on average $4.5 \%$ and $2.6 \%$ to coal power life cycle emissions, respectively. As freight is mostly transported with diesel engines (19), an increase of railway electrification may be the most effective emission reduction option. Transport emissions from trucks and barges are only relevant in individual cases. Other emissions from coal handling and storage as well as transport via coal slurry pipelines and belt conveyors are not included in this work due to lack of data. These are expected to have minor impacts on overall results $(20)$.

Globally, coal power plants are the main source for releases of the five priority emission categories GHG, $\mathrm{PM}_{2.5}, \mathrm{SO}_{2}$, $\mathrm{NO}_{x}$ and $\mathrm{Hg}$ into the air along the coal supply chain (figure 2). This is due to components of the fuel (for $\mathrm{CO}_{2}, \mathrm{PM}_{2.5}, \mathrm{SO}_{2}$, fuel $\mathrm{NO}_{x}$, and $\mathrm{Hg}$ ), but also due to complex reactions during 
(a) Total emission contributions

$\square$ Plants $\square$ Mines $\square$ Ocean $\square$ River $\square$ Rail $\square$ Road

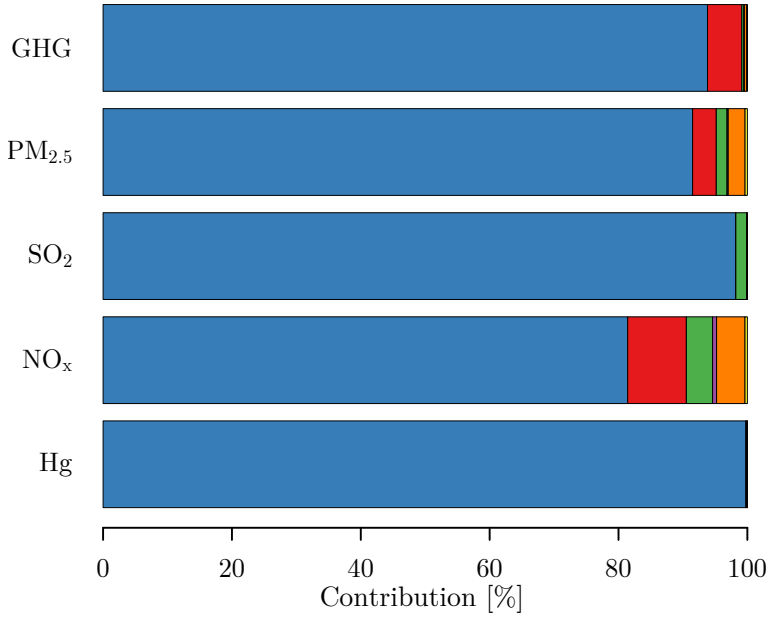

(c) $\mathrm{PM}_{2.5}$ emission contributions (all units)

$\square$ Plants $\square$ Mines $\square$ Ocean $\square$ River $\square$ Rail $\square$ Road

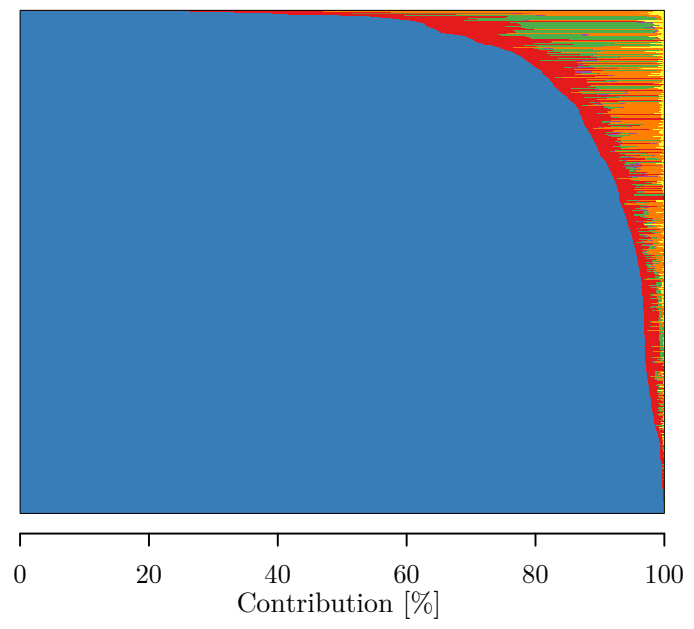

(e) $\mathrm{NO}_{\mathrm{x}}$ emission contributions (all units)

$\square$ Plants $\square$ Mines $\square$ Ocean $\square$ River $\square$ Rail $\square$ Road

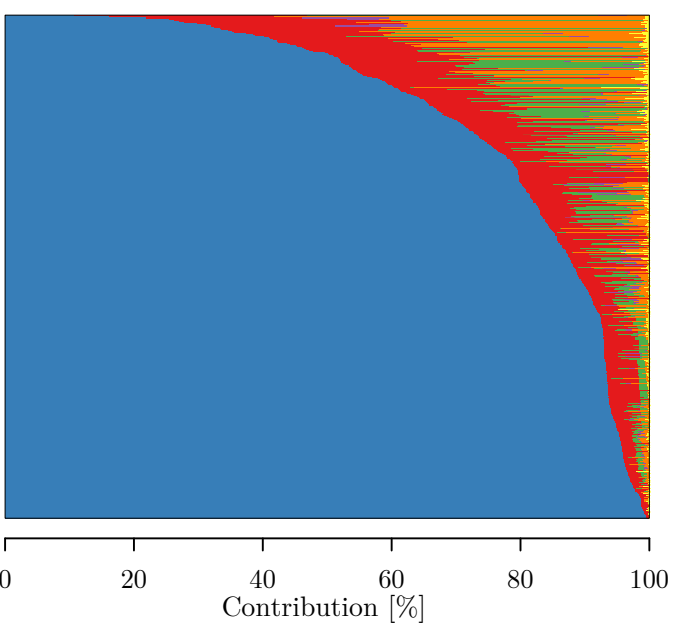

(b) GHG emission contributions (all units)

$\square$ Plants $\square$ Mines $\square$ Ocean $\square$ River $\square$ Rail $\square$ Road

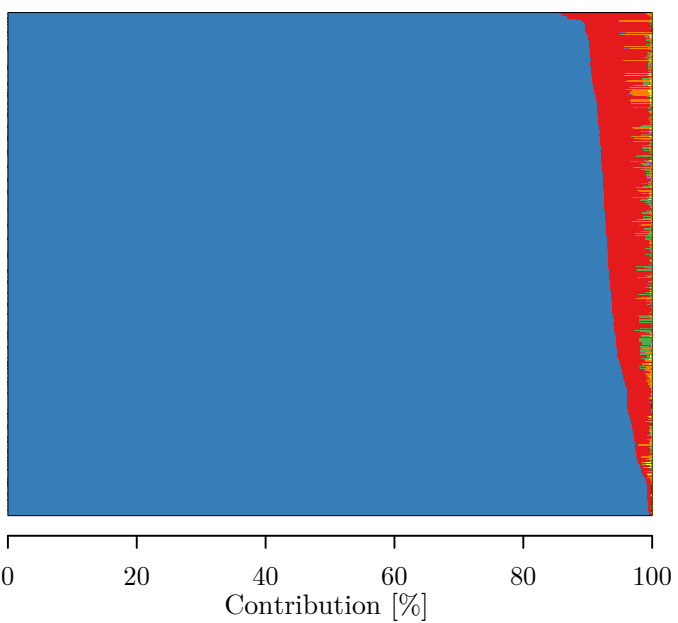

(d) $\mathrm{SO}_{2}$ emission contributions (all units)

$\square$ Plants $\square$ Mines $\square$ Ocean $\square$ River $\square$ Rail $\square$ Road

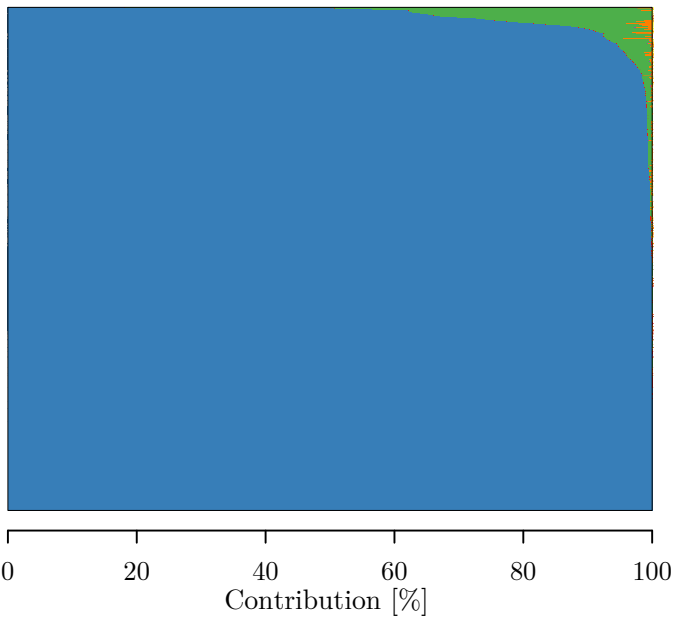

(f) $\mathrm{Hg}$ emission contributions (all units)

$\square$ Plants $\square$ Mines $\square$ Ocean $\square$ River $\square$ Rail $\square$ Road

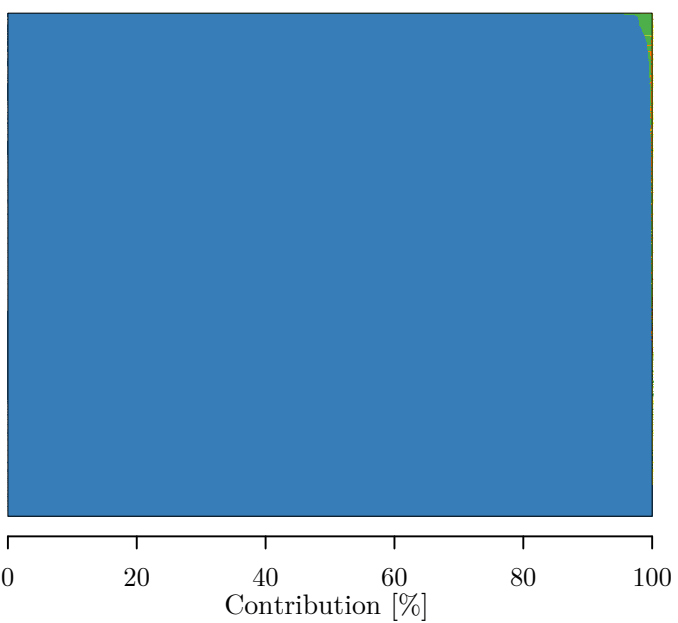

Fig. 2. (a) Coal mine, transport and coal power plant emission contributions to total emissions of coal power generation, as well as (b-f) contributions of individual coal generating units (y-axis) to pollutant emissions (sorted from largest power plant contribution to smallest). Contributions per unit from (b-f) add up to the sums in (a). GHG emissions given in GWP100. 
combustion (again for $\mathrm{PM}_{2.5}$ and $\mathrm{Hg}$, as well as thermal and prompt $\mathrm{NO}_{x}$ ) and flue gas treatment. Among all pollutants, coal power plants are on average responsible for $81 \%$ or more of the airborne supply chain emissions, and in the case of $\mathrm{Hg}$ for nearly $100 \%$ (figure 2e). Mercury emissions at power plants are dominated by elemental mercury $(69 \%)$ with smaller shares of ionic $(30 \%)$ and particulate mercury (1\%). More measured data on emissions per coal power plant is needed though, in order to reduce the considerable uncertainties associated with modeling emissions, especially in developing regions of the world and along the coal supply chain where emissions are not reported. A discussion of the data limitations, including those associated with mining emissions in particular, is provided in the supplementary information.

Variability of greenhouse gas emissions. Major differences of GHG emissions, including transport and mining, per net generation of electricity are shown in figure 3. The mean cradle-to-gate emission intensities per country are within a narrow range around the generation-weighted global mean of $1.13 \mathrm{~kg} \mathrm{CO}_{2 \mathrm{e}} \mathrm{kWh}_{\mathrm{e}}{ }^{-1}$ with a net generation-weighted standard deviation of $\pm 0.06 \mathrm{~kg} \mathrm{CO}_{2 \mathrm{e}} \mathrm{kWh}_{\mathrm{e}}{ }^{-1}$. However, the generationweighted standard deviations among individual generating units is substantially larger than between countries, globally at $\pm 0.14 \mathrm{~kg} \mathrm{CO}_{2 \mathrm{e}} \mathrm{kWh}_{\mathrm{e}}{ }^{-1}$ due to the existence of particularly efficient as well polluting units in most countries. For reduction of GHG emissions per kWh electricity, the latter should be targeted with priority.

Part of the GHG emissions per electricity generation is explained by net electrical efficiencies, which relate net electricity outputs to fuel heat inputs. These are anti-correlated to GHG emissions with a Pearson correlation coefficient $r$ of -0.89 as high GHG emission intensities coincide in many cases with low efficiencies. These efficiencies are particularly low for lignite combustion, which is why countries with larger shares of lignite in their fuel mix, like Germany and Russia, perform worse in terms of GHG emission intensities compared to China India and the US. However, Germany and Russia have a significant share of combined heat and power production from coal. When allocating the GHG emissions between these two co-products based on exergy content, GHG emissions per net electricity generation from coal power plants in Germany and Russia are lower than in China (figure 3). The US coal power plant emissions per net electricity generation are among the lowest in the world but cause the second largest GHG impacts from coal power generation globally after China due to the large amount of US coal power generation.

The overall efficiency of coal combustion is related to plant age. Old coal power plants (constructed before 1970) produce $11 \%$ of net electricity from coal and generally have higher median emission intensities than newer ones due to higher median net electrical efficiencies (supplementary figure 8). For coal power plants constructed between 1970 and 2000, the median net electrical efficiencies are similar (around $31.4 \%$ based on lower heating values). A new trend can be observed for coal power plants constructed since 2000. GHG emission intensities have continuously dropped, largely due to the additions of large, highly efficient super-critical and ultra super-critical coal power plants in China and India. However, less efficient coal power plants are still being deployed in many parts of the world $(21,22)$.

Individual coal properties play a vital role for emissions.
Bituminous coal has the highest calorific value per carbon content while anthracite, in contrast, has a higher energy content per weight but lower energy content per carbon. Thus, combustion of anthracite emits, on average, $7 \%$ more $\mathrm{CO}_{2}$ per $\mathrm{kWh}$ than bituminous coal. Subbituminous coal and lignite also cause higher $\mathrm{CO}_{2}$ emissions during combustion than bituminous coal (on average $15 \%$ higher), in part due to their high ash and water content and associated lower boiler efficiencies. The global share of lignite consumption has decreased steadily since the 1990s, thus contributing to reduced GHG emission intensities, but in absolute terms, its consumption remained stable while the consumption of the other coal ranks more than doubled (23).

Another factor in GHG emissions is the type of mining technology involved. When comparing emission intensities of China and India per $\mathrm{kWh}$ of electricity, the latter are lower despite lower efficiencies and a similar coal consumption mix. Mining methods in India and China differ substantially: $95 \%$ of Chinese coal is mined underground while $81 \%$ of coal in India stems from opencast mining (24). Underground mining releases higher amounts of methane which is why total Chinese coal bed methane emissions are more than 30 times higher than the Indian ones (25). As a result, mean Chinese mining emissions are $0.08 \mathrm{~kg} \mathrm{CO}_{2 \mathrm{e}} \mathrm{kWh}_{\mathrm{e}}{ }^{-1}$ as opposed to $0.02 \mathrm{~kg} \mathrm{CO}_{2 \mathrm{e}} \mathrm{kWh}_{\mathrm{e}}{ }^{-1}$ in India. This offsets the Chinese power plant net efficiency advantage of $5 \%$ by a factor of four.

There is a range of measures that can be applied to reduce GHG emissions from coal electricity generation. Efficiency improvements would be one such option, with improvement potentials of up to $15 \%$ at individual plants, but at high costs as shown by (26). Another option may be a (partial) fuel switch of coal power plants to natural gas or biomass where the required infrastructure is locally available. This has been practiced in the US recently due to a cheap local supply of alternate fuels $(27,28)$. Natural gas combustion may save up to $50 \%$ percent of GHG emissions at the power plants (29), while biomass has even lower net $\mathrm{CO}_{2}$ emissions. A future option may be carbon capture and storage (CCS), which sequesters $\mathrm{CO}_{2}$ from flue gas and stores it underground, but there are technical challenges, a lack of financial incentives and an increase in fuel demand, which have to be overcome (30). CCS has side-effects like a potentially toxic amine slip into the environment, and an increase of emissions along the supply chain due to additional coal inputs from efficiency losses, which make re-assessment of environmental and health impacts necessary once this technology reaches maturity.

Non-GHG emissions and health impacts. Unlike the global effects of GHG emissions, the health effects caused by primary $\mathrm{PM}_{2.5}, \mathrm{SO}_{2}, \mathrm{NO}_{\mathrm{x}}$ and $\mathrm{Hg}^{2+}$ are highly dependent on the location of the emission. They result from pollutant inhalation by humans $(31,32)$ and in the case of $\mathrm{Hg}^{2+}$ from ingestion of fish. The local population density surrounding the point of emission is thus one of the dominating parameters that determine absolute health impacts (31). We use regionalized life cycle impact assessment (LCIA) to quantify the health impacts from human exposure. Four regions show the highest health impacts globally: India, eastern China, parts of Europe and the US (figure 4).

PM-related health impacts in this study cause the loss of 8.8 $\mathrm{MDALY} \mathrm{a}^{-1}$, which is $11.2 \%$ of the total DALY loss due to ambient PM in 2012 according to (33). The contribution of 


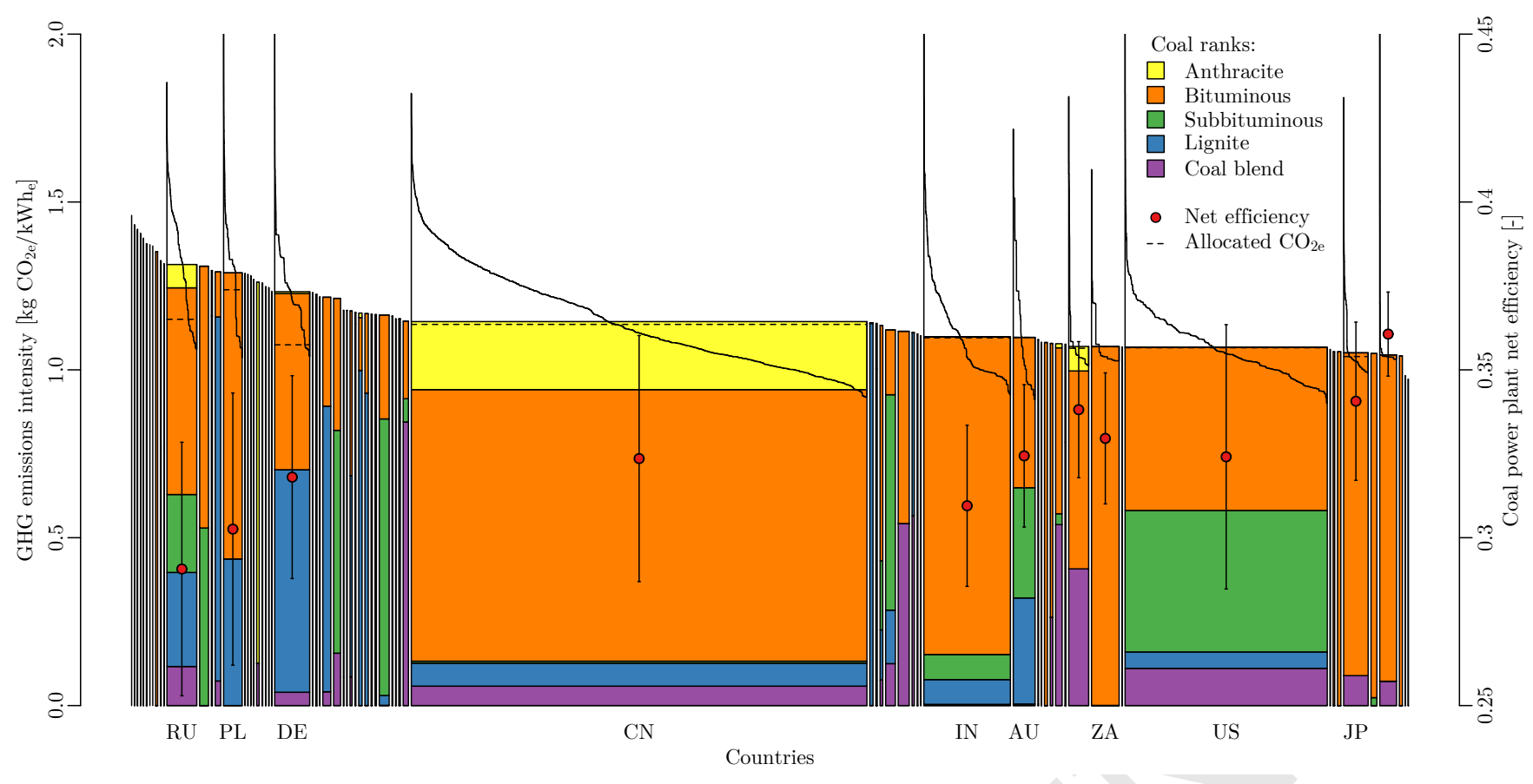

Fig. 3. Left axis: Mean $\mathrm{CO}_{2}$ emission equivalents of coal power plants per net electricity generation including mine and transport emissions without heat allocation. The widths of the bars are proportional to net generation, the colors indicate coal ranks. Black lines indicate GHG intensity distributions of individual coal power plants for major countries. GHG emission intensities above $2 \mathrm{~kg}^{\mathrm{CO}} \mathrm{e}_{2 \mathrm{e}} \mathrm{kWh}_{\mathrm{e}}{ }^{-1}$ are not shown. Right axis: The points show the generation-weighted mean electrical power plant net efficiencies per country based on lower heating values (LHVs), and the error bars the weighted standard deviations of these efficiencies. Dashed lines show GHG emission intensities in case of exergy allocation between electricity and heat. Country abbreviations: RU - Russia, PL - Poland, DE - Germany, CN - China, IN - India, AU - Australia, ZA - South Africa, US - United States, JP - Japan.

$\mathrm{SO}_{2}\left(6.1 \mathrm{MDALY} \mathrm{a}^{-1}\right)$ stands out in comparison to those of $\mathrm{NO}_{\mathrm{x}}\left(1.7 \mathrm{MDALY} \mathrm{a}^{-1}\right)$ and primary $\mathrm{PM}_{2.5}\left(1.0 \mathrm{MDALY} \mathrm{a}^{-1}\right)$. This is a result of the high sulfur content of coal in combination with unabated $\mathrm{SO}_{2}$ emissions and a large local exposure due to high population densities in major coal-burning countries like India (figure 4). $\mathrm{Hg}^{2+}$ human toxicity impacts are calculated to be lower than PM impacts at $0.2 \mathrm{MDALY} \mathrm{a}^{-1}$. It should be noted that impacts of $\mathrm{Hg}^{2+}$ are highly uncertain (around three orders of magnitude), as the exposure pathway via the food chain is subject to major model and parameter uncertainty (34). $\mathrm{Hg}^{2+}$ impacts occur over a long time frame, while respiratory effects are more immediate, which makes direct comparison difficult. Furthermore, a full global assessment of mercuryrelated health impacts is not yet included in (1).

Indian coal power plants cause the highest share of global coal combustion health impacts (figure 4b). One of the main reasons is the absence of $\mathrm{SO}_{2}$ control in India. Similarly, a lack of $\mathrm{NO}_{\mathrm{x}}$ control results in high $\mathrm{NO}_{x}$ pollution impacts. Finally, Indian coal is characterized by high mercury content with large regional variability (35), which also leads to increased mercury health impacts. Neither of these substances has been regulated at Indian coal power plants until 2015 (36), with the newly introduced regulation still not having resulted in major changes as of now (2018) due to implementation problems.

The Chinese situation is different. Modern coal power plants have been built in recent years, and policies restrict operation of plants close to major cities (37). Nevertheless, $\mathrm{PM}_{2.5}, \mathrm{SO}_{2}$ and $\mathrm{NO}_{x}$ emission and health risks are high, despite the installation of modern electrostatic precipitators (ESP), wet desulfurization technologies and low $\mathrm{NO}_{x}$ burners, due to the total amount of power generation from coal and generally high population densities. In particular, the health impacts from $\mathrm{Hg}^{2+}$ are larger than in other regions of the world (figure 4d), since raw coal is heavily contaminated with mercury (the median Chinese mercury concentration is $86 \%$ higher than elsewhere).

Europe has locally high population densities and many coal power plants in its eastern and south-eastern parts lack modern flue gas treatment or use low-quality coal. $\mathrm{SO}_{2}$ emissions especially are responsible for regionally high health impacts in these regions (figure $4 \mathrm{~b}$ ). $\mathrm{Hg}^{2+}$ emissions from some power plants in the United Kingdom are high in international comparison and cause elevated health impacts.

The case of the US is less severe since the population density is lower than in the three aforementioned regions. Still, we find above-average health impacts for $\mathrm{SO}_{2}$ in the eastern region where bituminous coal with high sulfur content is burned. Also, the share of coal in the US electricity mix is high, so while impacts per net electricity generation are lower than in many other parts of the world, the large amount of coal power generation makes the US the country with the fourth-highest coal power-related health impacts. These impacts are 18 times lower than in India.

Outside these regions, there are individual locations where health impacts are particularly high. This is typically associated with a combination of high population densities and poor flue gas treatment for example around Pretoria in South Africa, Moscow in Russia or Jakarta in Indonesia (figure 4a). These locations should be prioritized for emission reductions, as changes at few generating units lead to major health im- 
(a) Human health impacts per coal power plant [DALY/year]

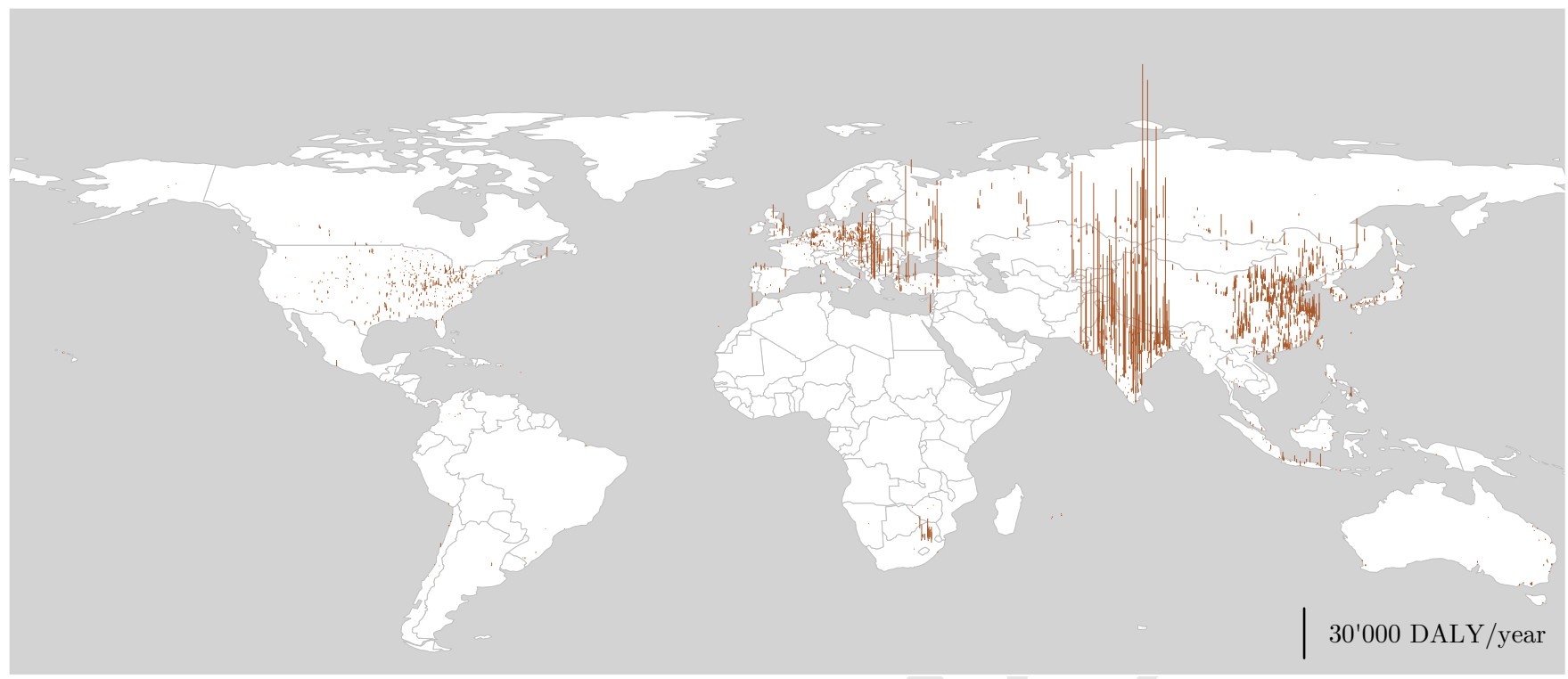

(b) Coal power plant health impacts per region

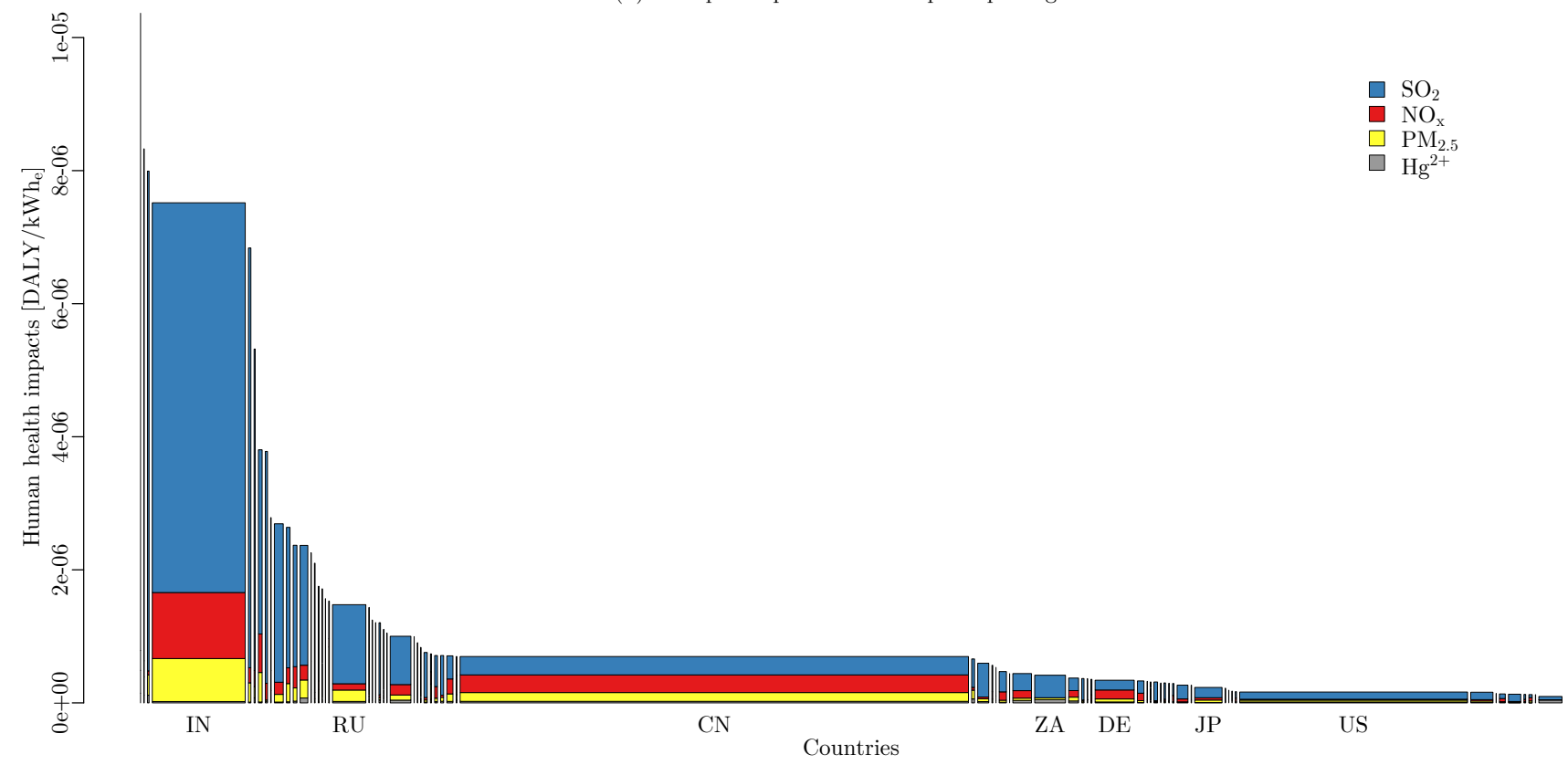

Fig. 4. (a) Human health impacts per coal power plant, and (b) as impact intensity per coal power production for each region and substance (areas of the bars are proportional to total impacts per region). $\mathrm{Hg}^{2+}$ impacts have been calculated with a different approach compared to $\mathrm{SO}_{2}, \mathrm{NO}_{x}$ and $\mathrm{PM}_{2.5}$ and are subject to high uncertainty (three orders of magnitude). Country abbreviations: IN - India, RU - Russia, CN China, ZA - South Africa, DE - Germany, JP - Japan, US - United States. 
provements.

Emission control. A general approach for reducing primary particulate matter emissions is through particulate removal with bag houses. These are up to $91 \%$ more effective at filtering $\mathrm{PM}_{2.5}$ particles out of the flue gas compared to current ESPs $(38,39)$. Bag houses are not used widely outside the US, as PM emission limits typically do not target $\mathrm{PM}_{2.5}$ specifically but instead $\mathrm{PM}_{10}$ or total PM (37). Health impact reductions from introduction of bag houses would mostly come from India and China, where primary $\mathrm{PM}_{2.5}$ health impacts are highest and cost-benefit ratios for $\mathrm{PM}_{2.5}$-removal are particularly favorable (as shown in the SI). Technical obstacles include an increased pressure drop in the flue gas stream and corrosion problems in the case of high shares of acidic components in the flue gas, but general feasibility is proven by 444 coal-fired generating units operating with baghouses in 2012. Upgrading $10 \%$ of global generating capacity to include bag houses could reduce primary PM health impacts by $47 \%\left(0.5 \mathrm{MDALY} \mathrm{a}^{-1}\right)$ with an additional benefit from reduced particulate mercury $\left(\mathrm{Hg}_{p}\right)$ releases. The costs for installing and operating bag houses are similar to those for ESPs (supplementary table 35 in the SI).

The health impacts from $\mathrm{SO}_{2}$ can be reduced with wet limestone injection. These reductions would come mostly from India where impacts are highest as there is no active $\mathrm{SO}_{2}$ control measure installed for $92 \%$ of the capacity in 2012 and persists until today (2018). The installation of wet limestone injection at the $10 \%$ most polluting coal generating capacity globally could result in $\mathrm{SO}_{2}$-related $\mathrm{PM}$ health impact reductions of $67 \%\left(4 \mathrm{MDALY} \mathrm{a}^{-1}\right)$. Co-benefits include reduced particulate and mercury emissions (38-40). As a consequence, local $\mathrm{PM}_{2.5}$ health impacts would be reduced by $21 \%\left(0.2 \mathrm{MDALY} \mathrm{a}^{-1}\right)$ and ionic mercury human toxicity impacts by $11 \%\left(0.02 \mathrm{MDALY} \mathrm{a}^{-1}\right)$.

Selective catalytic reduction (SCR) is an option for $\mathrm{NO}_{\mathrm{x}}$ health impact reduction. This technology is already employed by 1053 generating units in 2012. Utilization at all units can reduce $\mathrm{NO}_{\mathrm{x}}$-related $\mathrm{PM}$ health impacts by up to $58 \%$ $\left(1 \mathrm{MDALY} \mathrm{a}^{-1}\right)$, while upgrading $10 \%$ of generating capacity would reduce the coal power $\mathrm{NO}_{x}$ health impacts by $38 \%$ (0.6 $\left.\mathrm{MDALY} \mathrm{a}^{-1}\right)$.

While elemental mercury is a pollutant of global concern due to its stability in the atmosphere, ionic $\left(\mathrm{Hg}^{2+}\right)$ and particulate $\left(\mathrm{Hg}_{p}\right)$ mercury compounds deposit locally with rainfall and accumulate in the food chain by contaminating fish (41). Associated health impacts may be reduced from wet flue gas treatment or particulate removal (40), but the mercury then may enter the waste water and go to the sewage sludge (42) or end up in the retained fly ash. Its fate then depends on the individual use of sludge and fly ash, and is not fully understood. Injection of brominated pulverized activated carbon (PAC) is an option to adsorb elemental mercury from flue gas with a positive side-effect on $\mathrm{Hg}^{2+}$ (as well as $\mathrm{Hg}_{p}$ ). This is practiced by 160 generating units in 2012 and may further reduce total mercury emissions by up to $39 \%$ while also decreasing $\mathrm{Hg}^{2+}$ human toxicity impacts by $4 \%\left(0.007 \mathrm{MDALY} \mathrm{a}^{-1}\right)$. An alternative to upgrading flue gas treatment can be the phase-out of power plants in particularly sensitive areas and replacement with renewable alternatives. Health impacts depend strongly on local conditions at the power plant so the phase-out of few highly polluting units can lead to major health improvements.
To reduce corresponding health impacts by $50 \%$, the dirtiest $9 \%$ of global generating capacity for primary $\mathrm{PM}_{2.5}, 4 \%$ for $\mathrm{SO}_{2}, 12 \%$ for $\mathrm{NO}_{x}$ and $15 \%$ for $\mathrm{Hg}^{2+}$ would have to be phased out, respectively (as shown in detail in the SI).

The deployment of advanced flue gas treatment and the phase-out of old power plants is largely driven by local emission limits and their enforcement (39). In light of the plant-specific differences in health impacts per amount of pollutant release, we suggest to introduce plant-specific or region-specific legislation for pollutants with mostly local impacts. However, detailed site-specific fate and exposure modeling has to be conducted to set adequate emission limits and to avoid burden shifts between substances, locations, environmental compartments and impacts. The present paper allows to prioritize regions and power plants for more detailed assessments from a global perspective.

\section{Materials and Methods}

Overview and system boundaries. The emission inventory model for coal power plants in this work consists of three parts. It covers mine emissions, transport emissions and plant emissions. As such, it includes the airborne substance releases of carbon dioxide $\left(\mathrm{CO}_{2}\right)$, particulate matter in three size classes $\left(\mathrm{PM}_{>10}, \mathrm{PM}_{10-2.5}, \mathrm{PM}_{2.5}\right)$, sulfur dioxide $\left(\mathrm{SO}_{2}\right)$, nitrogen oxides $\left(\mathrm{NO}_{\mathrm{x}}\right)$, three species of mercury $\left(\mathrm{Hg}^{0}, \mathrm{Hg}^{2+}\right.$ and $\mathrm{Hg}_{p}$; from plants only, else as total $\mathrm{Hg}$ ), and methane $\left(\mathrm{CH}_{4}\right.$, from mines only) which are responsible for the main environmental impacts of coal power plants according to previous studies $(7,39)$. Airborne emissions during construction and de-construction of infrastructure are usually below $0.1 \%$ compared to emissions in the operation phase as presented in (7). Thus they were not modeled explicitly in the present study.

The system boundaries applied in this work are visualized in supplementary figure 1 .

Model structure. The model first sets up the databases for power plants, mines, transportation grid, coal samples, trade data, and reported emissions. In a second step, power plants and mines were connected by transport routes, and individual coal mixes were retrieved per power plant unit. A coal washing model was applied to account for coal preparation at the mines. Missing power plant data was imported from several databases if available, retrieved from satellite images or estimated and will be explained in more details in the following sections. Then, power plant emissions were imported from external data sources where possible, while for the remaining units, emissions were calculated based on technical power plant specifications, flue gas cleaning and coal properties. Regional mine and transport emissions were retrieved from ecoinvent v3.3 (cut-off system model) (19) with individual improvements on mine emissions to capture regional differences in more detail. Then, human health impacts for $\mathrm{PM}_{2.5}, \mathrm{SO}_{2}, \mathrm{NO}_{x}$ and $\mathrm{Hg}^{2+}$ emissions were calculated. An overview of the model structure is shown in supplementary figure 2. We developed the model in the programming language $\mathrm{R}$ (version 3.4.0) with the $\mathrm{R}$ packages listed in supplementary table 19.

Coal mining. A coal mine database was created from USGS minfac database $(\mathrm{n}=355)(43)$, Chinese USGS mine data $(\mathrm{n}=2440)(44,45)$, the Australian NPI database $(\mathrm{n}=114)(46)$, 
the Canadian NPRI database $(n=19)(47)$, European E-PRTR database $(n=342)(48)$, two EIA US coal mine data sources $(n=802$ and $n=460(49,50))$ and from satellite imagery $(n=705)$ based on the data reported in (51) (supplementary figure 4). Manually collected mine data is presented in supplementary table 12. Additionally, a consistent coal sample database with 9456 coal samples was created from the three USGS databases NaCQI (52), WoCQI $(53,54)$ and COALQUAL (55) as well as German lignite samples (56) by harmonizing data format, merging databases, converting units and removing duplicates. These also contain coal types for steel-making which could not be excluded as a clear distinction was not possible. Median values of coal constituents that have been obtained are shown in supplementary table 9. Lower heating values (LHVs) for the coal samples were calculated based on the enthalpies of coal constituents as described in the SI. Then, coal ranks were assigned. The four coal ranks are anthracite, bituminous coal, subbituminous coal, and lignite. The first two comprise hard coal with high calorific value, the latter two brown coal with low calorific value. This classification is internationally not consistent since exact criteria differ. Wherever needed, the most recent US guideline for classification (57) was used for consistency reasons and because most coal samples used in this study were collected and analyzed by the US Geological Survey (USGS). In case no coal rank could be assigned due to missing data, the originally reported coal rank was used instead. In the cases where US ranking standards were not followed, the ranks were converted with the rank correspondence shown in (58). The ranks of coal samples were also used to assign coal ranks to coal mines with missing rank information based on the closest coal sample contained in the coal sample database within $100 \mathrm{~km}$ (great circle distance, applied to $17 \%$ of coal mines). Remaining missing coal ranks of mines were filled in with coal ranks of the closest coal power plant within $100 \mathrm{~km}$ as coal is often burned locally (also by great circle distance, $6 \%$ of coal mines). Still remaining coal mines without coal rank $(3 \%)$ were assumed to produce bituminous coal as this is the dominant coal type globally (59).

To estimate emissions from mining, regional emission data per $\mathrm{kg}$ coal mined was taken from ecoinvent v3.3 (cut-off version) (19), which provides coal mine data sets for Australia, China, Indonesia, Poland, Latina America, North America, Russia, Western EU, South Africa, and the rest of the world for non-lignite coal while lignite is covered with a European and a rest of the world dataset (60). Methane emissions for non-lignite coal were updated based on national coal mining emissions (25) for the years 2010 to 2012 (taking the most recent available one) divided by corresponding production amounts from (61) (assuming these amounts as well as the original ecoinvent numbers referred to the production of washed coal). This was based on the assumption that lignite comes mostly from open pit mining with much lower methane emissions (as shown in (60)). As an exception, Turkey also mines lignite underground, which is why we divided total Turkish methane emissions by total Turkish coal production, and created both a lignite and a non-lignite coal mining dataset for Turkey. Emissions other than methane were taken from the ecoinvent region the countries are part of, so for example the US would have specific US methane emissions and North American PM emissions. Thus, updated and new non-lignite mining datasets could be generated for Argentina, Australia,
Brazil, Canada, Chile, China, Czech Republic, Germany, India, Italy, Malaysia, Mexico, New Zealand, Norway, Peru, Poland, Russia, Spain, Turkey, Ukraine, Great Britain, the United States, and Viet Nam, while also an additional lignite mining dataset was generated for Turkey (details including the calculated methane emissions per amount of coal are presented in supplementary table 18). Only on-site emissions (mining, blasting, diesel burning, and infrastructure emissions) were included and Chinese emissions from coal fires were removed for consistency reasons as they were not included in any of the other datasets. To make methane release comparable in terms of climate change impacts, these emissions were converted into $\mathrm{CO}_{2}$-equivalents based on IPCC guidelines by multiplying them with a factor for global warming potential of 28 for a 100-year perspective (12).

Coal washing. Coal washing is a set of mechanical and chemical processing steps, that aims at improving coal properties before transportation to the power plants. Specifically, it splits the coal into at least two fractions. The largest fraction has lower ash, sulfur and mercury content and higher calorific value and is sold, while any smaller, less pure fractions have lower economic value and are thus disposed or burned locally. Details on the modeling of coal washing are presented in the SI.

Transportation. The transportation model in this work serves two purposes. It allows the estimation of direct emissions and locations that come from transportation of raw coal from mines to power plants, as well as the estimation of the average blend of coal that goes into each power plant. Thus, a global coal transportation network was created that contains potential routes from mines to power plants via rivers, oceans, rail and road. River transport other than on main rivers were beyond the scope of this study. Belt conveyor transport as well as coal pipeline transport were also not modeled in this study since no sufficient information on its global use was available. Belt conveyors cover short distances up to a few kilometers and thus have little impact on total transport emissions from their energy demand. Fugitive emissions from belt conveyors though, as detailed in (62), could be a factor to include in future studies. Coal pipelines have existed in few regions of the world (for example the Black Mesa and the Consolidation pipelines in the US) but play no important role anymore. Thus, only data on the global rail network as well as shipping routes and major rivers for coal transport including coal ports was collected (details in the SI). The road network was approximated as also described there.

In a next step, the unlinked way points (mines, power plants and ports) and the individual transportation networks per mode were linked to create the full global coal transport network. The linking algorithm is shown in supplementary table 2. It consists of 21 steps, each of which either creates links between way points or removes previous links where more detailed data is available. A power plant for example may connect directly to a nearby ocean way point but in case there is an ocean harbor nearby, direct connections between power plants and ocean way points are removed and instead the connection is made via the coal port. This procedure ensures connectivity where local coal harbors at power plants are not known but allows for more accurate route estimates if they are known. Distance thresholds of $10 \mathrm{~km}, 100 \mathrm{~km}$ and $1000 \mathrm{~km}$ were set as 
upper limits to avoid unrealistic connections. One way point could be connected to all way points within these distance thresholds or just to the closest one. This procedure automatically created 4699 road segments, 264 river segments and 358 ocean route segments out of a total 433405 segments. The transport mode per connection type is also presented in supplementary table 2. After the linking procedure, the complete network was turned into a graph where edges represent the transport pathways and nodes the way points. Edge weights were based on multiplying the edge length calculated from their coordinates as great circle distances with transport cost per mode of transport as reported for truck, rail and barge in (63) and for ocean vessels as mean value of coal ocean transport costs from $(64,65)$. As a result, costs for truck transport were $0.08417 \mathrm{USD} \mathrm{tkm}^{-1}$, rail transport costs $0.01544 \mathrm{USD} \mathrm{tkm}^{-1}$, barge transport costs $0.00899 \mathrm{USD} \mathrm{tkm}^{-1}$ and ocean transport costs $0.00262 \mathrm{USD} \mathrm{tkm}^{-1}$. These represent Chinese conditions and in case of ocean transport global conditions, but ratios between transport modes were found similar to US conditions in $(66,67)$. Since these two are the main consumers of coal (China $47.7 \%$ and US $10.6 \%$ (59)), this seems to be a reasonable assumption.

To then satisfy the coal demands of the coal power plants, all plants were connected to mines based on the available data per plant. That included individual plant-level information on specific US mines (50), individual mine data per plant from (68), coal origin provinces for US power plants (69), domestic, imported or both types of coal per plant from IEA coal power atlas (70), province-level information for Chinese power plants from (71), IEA average coal mixes per country and coal rank for OECD countries (59), own calculations of country mixes per coal rank for non-OECD countries with major global relevance in the coal sector (China, India, Russia, Indonesia, South Africa, Colombia, Vietnam, Kazakhstan, Ukraine, Philippines) from $(72,73)$ and finally the multiregional input-output (MRIO) database exiobase 2 for the rest of the world (supplementary figure 6) (74). The shares for non-OECD countries were calculated from the production data per coal rank in 2012 minus the respective exports from (73) and adding the imports per coal rank from (72). Wherever production amounts were zero due to data gaps in (73), we calculated the minimal domestic production from the total coal demand per coal rank we knew from our coal power plant database (for example for anthracite production in China). Results are shown in supplementary tables 26-29. For Chinese coal power plants without plant-specific coal source data, we combined these shares with province-level coal origin data (71) for the domestic coal consumption. Countries without explicit representation in exiobase 2 were assumed to have coal demands representative of the larger region they are located in (Chile for example was treated as Rest of World America).

To calculate the cheapest reachable mine per power plant within each supplying mining region, the Dijkstra algorithm (75) was used. Only mines offering the required coal rank (anthracite, bituminous, subbituminous, lignite) were allowed to supply coal to a power plant. For power plants that blended coal, weight shares were based on the average coal supply to that region (again from IEA data (73) for OECD nations, own calculations for large coal-consuming non-OECD nations, and from exiobase for the remaining countries (74)).

Specific regional coal properties (lower heating value, sulfur content, ash content, water content, mercury content, chloride content) were assigned to each coal mine. For anthracite, bituminous and subbituminous coal, these were the median values per province, for lignite the values of the closest coal sample. This distinction was made because low value lignite is typically only supplied to the closest power plants within reach due to transportation costs. For the other coal types, transportation takes place over larger distances, so the share of transportation costs in comparison to total fuel costs is larger and so a more suitable coal might get chosen with little additional cost. Thus, we calculated average coal mixes per province as we considered these more representative. In case there were data gaps for individual properties, these were filled from country-level data of the same coal rank, and if that was not possible also from global data of the same rank. Global average properties were calculated as production-weighted mean values $(72-74)$.

Based on the shares of coal input from different regions and coal ranks, the weighted mean coal properties per kilogram of coal at the plant were calculated. Then, the total coal consumption in $\mathrm{kg}$ was estimated with the average lower heating value to satisfy the heat input requirement per plant. The total coal consumption was then split to all routes connecting the mines according to the coal amount shares calculated before. Mine capacity restrictions were not taken into account as data on these were not available globally.

An appropriate ecoinvent v3.3 data set was assigned to each transport route segment based on transport mode and location (selected data sets and regions listed in supplementary table 32; ship transport was global, for barge as well as truck it was specific to Europe and the Rest of the World, and for trains it was specific to Austria, Belgium, China, France, Germany, Italy, Switzerland, US, Rest of Europe and the Rest of the World) (19). It was then possible to quantify the direct emissions along the individual transport routes from the transported coal mass per segment and its length. These emissions do not include indirect emissions such as from manufacture of vehicles, maintenance, or electricity demands as these are not emitted along the transport route.

Power plants. Operational coal power plant units in 2012 were taken from the Platts WEPP database (76) while corresponding locations were obtained from emission registers and related databases $(47,48,77)$ or from (78) and (79) (supplementary figure 3). Estimation of airborne emissions per plant unit then followed a two-tiered approach: Preferably, airborne emissions were used from publicly reported data as this is considered to yield the most accurate representation of actual emissions. These were available to varying degrees for China (80-82), India (83), the countries in Europe (48), the US (84), Australia (46), Canada (47), South Africa (85) and Japan (86). Only if data was missing, models for the individual pollutant releases were used. These were based on material balances and, in part, on empirical equations as described in detail in the SI. Flue gas treatment data to quantify emission abatement and resulting emissions per generating unit was obtained from several data sources $(76,80-82)$ and from satellite imagery.

Quantification of health impacts. Regional characterization factors (CFs) for PM health impacts of $\mathrm{SO}_{2}, \mathrm{NO}_{x}$ and $\mathrm{PM}_{2.5}$ emissions have been obtained from the life cycle impact assessment (LCIA) method of (87) (choice is explained in the SI). 
This LCIA method provides characterization factors mostly on a country level. The coordinates of point sources have been used to identify the CFs with CF maps made available by (88). The global average $\mathrm{CF}$ was assigned to all coordinates outside the geographic boundaries in (88) (applies to 254 coal generating units accounting for $5.2 \%$ of global coal power generation capacity). Emissions were multiplied with the geographically corresponding CFs to quantify health impacts. Alternative approaches for $\mathrm{SO}_{2}, \mathrm{NO}_{x}$ and $\mathrm{PM}_{2.5}$ health impacts from (31) and for $\mathrm{PM}_{2.5}$ impacts from $(89,90)$ have additionally been applied and compared in the SI. For $\mathrm{Hg}^{2+}$ health impacts, the characterization factors from (91) have been used based on the classification of urban and rural regions described in the SI.

Acknowledgements. We thank Christie Walker for proofreading our manuscript, Christian Bogdal and Basil Denzler for advice on mercury health impacts, and Simon Stocker and Musuizi Lei for their contributions on coal washing and collection of Chinese power plant data.

Author contributions. $\mathrm{CO}, \mathrm{SP}$ and $\mathrm{SH}$ designed the research; $\mathrm{CO}$ collected the data and did the modeling with contributions from $\mathrm{CR}$; $\mathrm{CO}$ and $\mathrm{SP}$ interpreted the results; $\mathrm{CO}$ wrote the paper with inputs from SP, CR and SH.

Competing interests. We declare no competing interests.

Materials and correspondence. Detailed descriptions of existing research, extended methods, additional results, discussion of policy relevance, limitations of this work, uncertainties, and recommendations for future work are available in the SI. The emission dataset per power plant and the source code for the model is available at http://dx.doi.org/10.17632/dm3rjb9ymc.1 (92). For specific questions or data requests, please contact the authors directly at oberschelp@ifu.baug.ethz.ch.

\section{References}

1. GBD 2017 DALYs and HALE Collaborators (2018) Measuring progress from 1990 to 2017 and projecting attainment to 2030 of the health-related Sustainable Development Goals for 195 countries and territories - a systematic analysis for the Global Burden of Disease Study 2017. The Lancet 392(10159):2091-2138.

2. World Health Organization (2006) WHO Air quality guidelines for particulate matter, ozone, nitrogen dioxide and sulfur dioxide - Global update 2005 - Summary of risk assessment (Geneva, CH). Available online at http://apps.who.int/iris/bitstream/handle/10665/69477/ WHO_SDE_PHE_OEH_06.02_eng.pdf?sequence $=1$.

3. World Health Organization (2018) Ambient (outdoor) air quality and health (WHO) Available online at http://www.who.int/news-room/fact-sheets/detail/ambient-(outdoor) - air-quality-and-health.

4. Pirrone N, et al. (2010) Global mercury emissions from natural and anthropogenic sources. Atm Chem Phys 10:5951-5964.

5. Ummel K (2012) CARMA revisited: An updated database of carbon dioxide emissions from power plants world wide (Washington DC). Working paper 304.

6. Steinmann Z, et al. (2014) How to address data gaps in life cycle Inventories - a case study on $\mathrm{CO} 2$ emissions from coal electricity. Env Sci Techn 48:5282-5289.

7. Spath PL, Mann MK, Kerr DR (1999) Life Cycle Assessment of Coal-fired Power Production.

8. Holland M, Berry J (1995) ExternE - Externalities of Energy, Volume 1 - Summary (Ox fordshire, UK). Published by the European Commission, Directorate General XII, Science, Research, and Development.

9. Institute of Studies for the Integration of Systems (2009) NEEDS - New Energy Externalities Developments for Sustainability - Publishable Final Activity Report.

10. Treyer K, Bauer C (2016) Life cycle inventories of electricity generation and power supply in version 3 of the ecoinvent database - part I: electricity generation. Int J LCA 21(9):12361254.

11. Tong D, et al. (2018) Targeted emission reductions from global super-polluting power plant units. Nature Sustainability 1:59-68.

12. Intergovernmental Panel on Climate Change (IPCC) (2013) Climate Change 2013: Synthesis Report. Contribution of Working Groups I, II and III to the Fifth Assessment Report of the Intergovernmental Panel on Climate Change IPCC.

13. Sloss $L$ (2005) Coalbed methane emissions - capture and utilisation (IEA Clean Coal Centre, London).
14. Attalla M, Day S, Lange T, Lilley W, Morgan S (2008) NOx emissions from blasting operations in open-cut coal mining. Atm Env 42(34):7874-7883.

15. Carras A, Day S, Saghafi A, Roberts O (2005) Spontaneous Combustion in Open Cut CoalMines - Recent Australian Research in Coal2005 Conference.

16. International Transport Forum (ITF) (2013) ITF Transport Outlook 2013 (Paris).

17. National Research Council of the National Academies (2007) Coal Research and Development to Support National Energy Policy. (National Academic Press), pp. 80-90.

18. Norris J, Ntziachristos L, Samaras Z, Zierock K (2013) Railways. EMEP/EEA emission inventory guidebook.

19. Ecoinvent centre (2016) Ecoinvent v3.3 database - cut-off system model (Zurich, Switzerland).

20. Carpenter AM (1999) Management of coal stockpiles (CCC/23). IEA Coal Research.

21. International Energy Agency (IEA) (2014) Energy Technology Perspectives 2014 - Harnessing Electricity's Potential (Paris).

22. Barnes I (2018) HELE Perspectives for Selected Asian Countries (CCC/287) (IEA Clean Coal Centre, London).

23. International Energy Agency (IEA) (2018) World - Coal supply (Paris). http://dx.doi.org/10 1787/data-00465-en. Retrieved on 2018-08-03.

24. Bian Z, Inyang H, Daniels J, Otto F, Struthers S (2010) Environmental issues from coal mining and their solutions. Mining Sci Techn (China) 20(2):215-223.

25. United Nations Framework Convention on Climate Change (UNFCCC) (2018) Greenhouse Gas Inventory Data - Detailed data by Party (New York City, NY, US). http://di.unfccc.int/ detailed_data_by_party. Retrieved on 2018-07-20.

26. U.S. Energy Information Administration (EIA) (2015) Analysis of Heat Rate Improvement Potential at Coal-Fired Power Plants (Washington DC).

27. Macmillan S, Antonyuk A, Schwind H (2013) Gas to Coal Competition in the U.S. Power Sector (Paris).

28. Intergovernmental Panel on Climate Change (Geneva, $\mathrm{CH}$, 2007) Climate Change 2007: Synthesis Report. Contribution of Working Groups I, II and III to the Fourth Assessment Report of the Intergovernmental Panel on Climate Change IPCC.

29. U.S. Environmental Protection Agency (EPA) (2015) Emission Factors for Greenhouse Gas Inventories.

30. International Energy Agency (IEA) (2016) 20 Years of Carbon Capture and Storage - Accelerating Future Deployment (Paris).

31. Fantke P, et al. (2016) Global Guidance for Life Cycle Impact Assessment Indicators - Volume 1. (United Nations Environment Programme (UNEP)), pp. 76-99.

32. United Nations Environment Programme (UNEP) (2015) Global Mercury Modelling - Update of Modelling Results in the Global Mercury Assessment 2013.

33. GBD 2016 DALYS and HALE Collaborators (2017) Global, regional, and national disabilityadjusted life years (DALYs) for 333 diseases and injuries and healthy life expectancy (HALE) for 195 countries and territories, 1990-2016: a systematic analysis for the Global Burden of Disease Study 2016. The Lancet 390:1260-344.

34. Rosenbaum R, et al. (2008) USEtox - the UNEP-SETAC toxicity model: recommended characterisation factors for human toxicity and freshwater ecotoxicity in life cycle impact assessment. Int J LCA 13(7):532-546.

35. Burger Chakraborty L, Qureshi A, Vadenbo C, Hellweg S (2013) Anthropogenic Mercury Flows in India and Impacts of Emission Controls. Env Sci Techn 47(15):8105-8113.

36. Central Pollution Control Board (CPCB) - Government of India (2015) Ministry of Environment, Forestry and Climate Change Notification - New Delhi, the 7th December, 2015 - Environment (Protection) Amendment Rules, 2015. The Gazette of India: Extraordinary - No. 2620 - Part II - Section 3 - Subsection (ii).

37. International Energy Agency (IEA) - Clean Coal Centre (2017) Emission standards (London). http://www.iea-coal.org.uk/site/2010/database-section/emission-standards. Retrieved on 2017-12-11.

38. Cai W, Wang C, Jin Z, Chen J (2013) Quantifying Baseline Emission Factors of Air Pollutants in China's Regional Power Grids. Env Sci Techn 47(8):3590-3597.

39. European Commission - Joint Research Centre (2017) Best Available Techniques (BAT) Reference Document for Large Combustion Plants (Seville, Spain)

40. U.S. Environmental Protection Agency (EPA) (2004) Control of Mercury Emissions from Coalfired Electric Utility Boilers.

41. Sloss L (2002) Mercury - emissions and control (IEA Clean Coal Centre, London).

42. S. Balogh S, Liang L (1995) Mercury pathways in municipal wastewater treatment plants. Water, Air, and Soil Pollution 80(1-4):1181-1190.

43. Eros JM, et al. (2010) Mineral operations outside the United States (minfac) (Reston, US).

44. Trippi MH (2014) AllChinaCoalMines (Reston, US).

45. Trippi MH, Belkin HE, Dai S, Tewalt SJ, Chou CJ (2014) USGS Compilation of Geographic Information System (GIS) Data of Coal Mines and Coal-Bearing Areas in China.

46. Australian Government - Department of the Environment and Energy (2012) National Pollutant Inventory (NPI).

47. Canadian Environmental Assessment Agency (CEAA) (2012) National Pollutant Release Inventory (Gatineau, CA)

48. European Environment Agency (EEA) (2017) European Pollutant Release and Transfer Register (E-PRTR) (DK).

49. U.S. Energy Information Administration (EIA) and the U.S. Department of Labor, Mine Safety and Health Administration (2014) Coal Mines, Surface and Underground.

50. U.S. Energy Information Administration (EIA) (2017) Coal. https://www.eia.gov/opendata/ bulkfiles.php. Retrieved on 2017-10-12.

51. Walker S (2010) Major coalfields of the world (2nd edition), CCC/32. (International Energy Agency - Clean Coal Centre).

52. Finkelman R (2005) National Coal Quality Inventory (NACQI).

53. Tewalt SJ, Willett JC, Finkelman RB (2005) The World Coal Quality Inventory: A status report. Int J Coal Geol 63:190-194.

54. Tewalt S, et al. (2010) Chemical analyses in the World Coal Quality Inventory, version 1 (Reston, VA, US). 
55. United States Geological Survery (USGS) (2015) COALQUAL database.

56. DEBRIV - Bundesverband Braunkohle (1999) Lignite - An industry takes a bow (Cologne). https://www.braunkohle.de/index.php?article_id=98\&fileName=debriv02_en.pdf. Retrieved on 2017-08-14.

57. American Society for Testing and Materials (ASTM) (2015) ASTM D388-15 - Standard Classification of Coals by Rank.

58. Walker S (1993) Major coalfields of the world, CR/51. (International Energy Agency - Clean Coal Centre).

59. International Energy Agency (IEA) (2013) Coal Information 2013 (Paris).

60. Donnes R, Bauer C, Roder A (2007) Ecoinvent Report No. 6-VI - Kohle - Data v2.0 (Villigen, Switzerland).

61. International Energy Agency (IEA) (2017) World Energy Balances 2017 (Paris)

62. Schmitz J (1994) Control of coal dust in transit and in stockpiles (IAEPER15) (IEA Clean Coal Centre, London).

63. Tu KJ (2011) Industrial Organization of the Chinese Coal Industry (Stanford, US).

64. International Seaborne Market (2014) Panamax/Cape freight market. Coal shipping costs // week 17. http://me-freight.com/news/open/F4DDF14C5F23FC13C2257CC5004B52E3Q= PanamaxCape-freight-market-Coal-shipping-costs. Retrieved on 2017-10-04.

65. International Seaborne Market (2014) Handy freight market. Coal shipping costs /I week 17. http://me-freight.com/news/open/C0DE8327F54346A6C2257CC5003F41EBQ= Handy-freight-market-Coal-shipping-costs. Retrieved on 2017-10-04.

66. Forkenbrock D (2001) Comparison of external costs of rail and truck freight transportation. Transp Res A: Pol Pract 35(4):321-337.

67. U.S. Energy Information Administration (EIA) (2017) Coal Transportation Rates to the Electric Power Sector. https://www.eia.gov/coal/transportationrates. Retrieved on 2017-08-12.

68. Gupta R, Shankar H (2016) Global Energy Observatory. http://globalenergyobservatory.org/. Retrieved on 2016-11-10.

69. National Energy Technology Laboratory (NETL) (2007) Coal Power Plant Database (CPPDB) 2005. Retrieved on 2015-09-30.

70. International Energy Agency (IEA) - Clean Coal Centre (2010) Coal Power Atlas (London). Retrieved on 2017-10-11.

71. Su S, Li B, Cui S, Tao S (2011) Sulfur Dioxide Emissions from Combustion in China: from 1990 to 2007. Env Sci Techn 45(19):8403-8410.

72. United Nations (2017) UN Comtrade Database. Retrieved on 2017-10-24

73. International Energy Agency (IEA) (2017) World Coal supply, IEA Coal Information Statistics (database) (Paris). Retrieved on 2017-12-11.

74. Tukker A, et al. (2013) EXIOPOL - Development and illustrative analyses of detailed global MR EE SUT/IOT. Econ Sys Res 25(1):50-70.

75. Dijkstra EW (1959) A note on two problems in connexion with graphs. Numerische Mathematik 1(1):269-271.

76. Platts (2012) World Electric Power Plants Database (WEPP), March 2012.
77. U.S. Environmental Protection Agency (EPA) (2014) Emissions \& Generation Resource Integrated Database (eGRID) 2012

78. Raptis CE, Pfister S (2016) Global freshwater thermal emissions from steam-electric power plants with once-through cooling systems. Energy 97:46-57.

79. Raptis C, Oberschelp C, Pfister S (2018) The carbon, water scarcity, and thermal footprin of global thermoelectric power generation: a spatially explicit database and analysis. In preparation.

80. China Electricity Council (2013) Notice on Publicizing 2012 Energy Efficiency Targets and Competition Data of 600MW Thermal Power Units in China (in Chinese). Retrieved on 2017 10-11.

81. China Electricity Council (2013) Notification on Publicizing the Energy Efficiency Benchmarking and Competition Data of the 300MW Thermal Power Unit in China (in Chinese). Retrieved on 2017-10-11.

82. China Electricity Council (2014) Notice on Publicizing 2013 Energy Efficiency Targets and Competition Data of 300MW Thermal Power Units in China (in Chinese). Retrieved on 2017 10-11.

83. Central Electricity Authority (CEA) (2014) CO2 baseline database for the Indian power sector, Version 10.0

84. U.S. Environmental Protection Agency (EPA) (2013) Toxics Release Inventory (TRI) https://www.epa.gov/toxics-release-inventory-tri-program. Retrieved on 2016-02-07.

85. Eskom (2014) ConsumptioData2010-14 - Eskom CDM Grid information for application within the CDM. Retrieved on 2015-10-16

86. Ministry of the Environment - Government of Japan (2014) PRTRkensakun. Retrieved on 2017-01-20.

87. van Zelm R, Preiss P, van Goethem T, van Dingenen R, Huijbregts M (2016) Regionalized life cycle impact assessment of air pollution on the global scale: Damage to human health and vegetation. Atm. Env. 134:129-137.

88. Verones F, et al. (2016) LC-Impact Version 0.5. Characterization factor maps available at http://lc-impact.eu/downloads-characterisation-factors. Retrieved on 2018-07-20.

89. Fantke P, et al. (2017) Characterizing Aggregated Exposure to Primary Particulate Matter: Recommended Intake Fractions for Indoor and Outdoor Sources. Env. Sci. Techn. 51(16):9089-9100.

90. Fantke P (2018) Fantke P, Jolliet O, Apte J, Hodas N, Evans J, Weschler C, Stylianou K Jantunen M, McKone T - PM2.5 Emission-to-Exposure Model - Model for characterizing indoor and outdoor exposure from indoor and outdoor PM2.5 sources - 1.01 (corrective update version) - 2018-11-15. Personal communication.

91. Fantke P, et al. (2017) USEtox (corrective release 2.1). Available online at https://www.usetox. org/model/download/usetox2.1.

92. Oberschelp C, Pfister S, Raptis CE, Hellweg S (2019) Global coal power plant airborne emission dataset. Mendeley Data. Available online at http://dx.doi.org/10.17632/dm3rjb9ymc.1. 